\title{
ANTONIO CANDIDO: A DIALÉTICA ENTRE O LOCAL E O UNIVERSAL
}

\author{
ANTONIO CANDIDO: \\ THE DIALECTIC BETWEEN LOCAL AND UNIVERSAL
}

Candice Carvalho ${ }^{1}$

Doutorado pela UNESP

\begin{abstract}
RESUMO
O artigo propõe delinear a concepção de literatura em Antonio Candido mediante uma leitura combinada da dialética entre o local e o universal em seus escritos. Num primeiro momento, o texto retraça a trajetória intelectual do crítico e enfoca alguns dos aspectos mais fecundos de seu projeto do ponto de vista do método e de seus fundamentos. $\mathrm{Na}$ sequência, analisam-se os procedimentos que alicerçam seu juízo acerca do romance de Guimarães Rosa.
\end{abstract}

PALAVRAS-CHAVE: Antonio Candido; Crítica brasileira; Método de análise literária; Guimarães Rosa.

\begin{abstract}
The article proposes to outline Antonio Candido's conception of literature by reading the dialectic between local and universal in his works. Initially, the text retraces the critic's intellectual trajectory and focus on some more prolific aspects in his project, from the point of view of method and its grounds. Subsequently, it analyzes the procedures that support his judgment about Guimarães Rosa's romance.
\end{abstract}

KEYWORDS: Antonio Candido; Brazilian Criticism; Literary Analysis Method; Guimarães Rosa.

\section{Antonio Candido e a crítica literária no Brasil}

Toda escolha tem uma história. Uma história que não é só pessoal, mas tem a ver
com o ethos de uma geração que compartilhou durante algum tempo as mesmas
perplexidades no plano das ideias e no plano dos valores.
Entre a literatura e a história, Alfredo Bosi (2013, p. 243).

Numa entrevista de 1974, Antonio Candido (2011) distingue três etapas principais em seu percurso teórico, correspondentes aos anos 1940, 1950 e 1960. Sob o impacto da visão positivista da cultura em que se assentava o marxismo, a primeira delas se voltou para a busca dos condicionantes sociais e psicológicos que presidem à composição artística. É o caso da tese $O$ método crítico de Sílvio Romero, escrita entre 1944 e 1945, que marca o ponto de partida das posições críticas às quais chegaria Candido mais tarde, conforme revela o próprio autor no prefácio da segunda edição do livro. Essas posições estão concretizadas sobretudo em Formação da literatura brasileira (1959) e nalgumas das peças coligidas em Literatura e sociedade (1965) e Tese e antítese (1964), que reúnem textos produzidos ao longo dos anos 1950 e no início dos anos 1960.

\footnotetext{
1 Doutora em Estudos Literários pela UNESP - Universidade Estadual Paulista "Júlio de Mesquita Filho". Faculdade de Ciências e Letras, câmpus de Araraquara - Programa de Pós-Graduação em Estudos Literários. E-mail: candicedecarvalho@uol.com.br.
} 
A tese sobre os fundamentos da crítica romeriana leva Candido a notar que a leitura de inspiração sociológica poderia ser limitadora do conhecimento da literatura, quando concebida como "critério exclusivo, ou mesmo central, de interpretação" (CANDIDO, 1988, p. 15). Todavia, a relação entre literatura e sociedade permaneceria em seu percurso intelectual e ele buscaria determinar como, na ficção literária, os estímulos externos (psíquicos e sociais) se tornam parte de uma realidade interna, definindo a estrutura específica da composição artística. Com efeito, é possível reconhecer no trabalho sobre o método de Sílvio Romero uma sondagem discreta e programática da articulação e/ou mediação entre análise interna e análise das condições históricas - fundamento, sabemos, da produção madura do autor: "Esse duplo movimento, na tese de 1945, anuncia um procedimento crítico que vai perpassar toda a trajetória de Antonio Candido, ganhando formulações variadas, mas acenando sempre para essas dimensões interna e externa e o nexo que as articula" (WAIZBORT, 2007, p. 90).

Vale lembrar que, no início dos anos 1940, Candido iniciava a militância da crítica literária junto ao círculo de intelectuais do grupo Clima, formado por jovens universitários da nascente Faculdade de Filosofia, Ciências e Letras (cuja implantação data de 1934) da Universidade de São Paulo. Eram também membros desse círculo, entre outros: Paulo Emílio Sales Gomes, Décio de Almeida Prado, Lourival Gomes Machado, Ruy Coelho, Gilda de Mello e Souza. Por meio da análise interna de modalidades diversificadas da cultura (a crítica aplicada ao cinema, ao teatro, à literatura e às artes plásticas), com apoio nas modernas ciências humanas e em métodos de pesquisa intrinsecamente acadêmicos, aprendidos em grande parte com notáveis professores estrangeiros na universidade paulista, como o filósofo marxista Jean Maugüé, a revista editada pelo grupo (entre maio de 1941 e novembro de 1944, com algumas interrupções) demarcava a diferença em relação aos padrões intelectuais e convenções dominantes na época. ${ }^{2}$ Socializava um novo estilo de raciocínio crítico, pautado por visadas mais amplas, projetos de intervenção e correlações mais complexas, capaz de lançar uma ponte de mão dupla entre as linhas centrais do passado e as demandas intelectuais de seu tempo. Por isso sua circulação, embora estrita (nunca mais de 1.000 exemplares em cada uma das 16 edições), causou grande impacto na cena cultural de São Paulo, sendo recebida com admiração e fascínio, mas também com ressalvas, inclusive pelos modernistas de $1922 .^{3}$

Com o lastro de marco inaugural, essa publicação de juventude permitiu ao grupo conquistar a projeção e o reconhecimento necessários para que seus membros se inserissem noutros órgãos da imprensa e em empreendimentos intelectuais mais ambiciosos da capital paulista. Ao lado de importantes nomes do jornalismo crítico - como Álvaro Lins, Otto Maria Carpeaux, Sérgio Buarque de Holanda, Paulo Rónai, Lúcia Miguel Pereira, Augusto Meyer e Sérgio Milliet -, Candido atuaria como crítico literário titular no jornal Folha da Manhã (entre janeiro de 1943 e janeiro de 1945), posteriormente passando ao Diário de São Paulo (no qual atuou entre setembro de 1945 e fevereiro de 1947). A originalidade e o rigor analítico que caracterizam os rodapés semanais dos dois jornais paulistanos davam amostras da versatilidade da personalidade crítica em formação, cujos traços se propagariam nos escritos de maturidade mediante sucessivos alargamentos e reavaliações. A mesma coluna que se ocupava dos procedimentos estéticos de manifestações internacionais, tais como a poética de T. S. Eliot, o romance de Silone, as posições de Gide, a autobiografia de Trotsky e a filosofia de Nietzsche, tratou de estreias decisivas de autores brasileiros, como as de Clarice Lispector, João Cabral e Guimarães Rosa. "A vizinhança entre a produção local e as grandes tendências contemporâneas em arte, política e filosofia, provocada pela abertura de espírito dominante nesses rodapés, configura um programa de desprovincialização e clarificação da cena cultural” (SCHWARZ,

${ }^{2}$ Sobre a importância do filósofo francês J. Maugüé, merece leitura "Jean Maugüé, un obscur éclat", de A. Candido (2005). A respeito da presença de professores estrangeiros na Universidade de São Paulo, consultar, entre outros, Um departamento francês de ultramar, de P. E. Arantes (1994).

${ }^{3}$ A respeito desse impacto, ver também A. Candido (2007); H. Pontes (1998; 2009). 
1999, p. 9-10). A disposição experimental que subjaz da "paixão do concreto", definida como o traço de sua geração, repercutiria nas várias dimensões da trajetória substantiva de Antonio Candido como pesquisador e professor no campo das letras, sobretudo na sua concepção modelar da crítica literária e no perfil inovador das suas práticas de análise, a um só tempo capazes de penetrar a singularidade de cada obra e transitar dinamicamente as relações entre a literatura e o seu entorno social e histórico.

Nos meados dos anos 1940, os rodapés começam a se esparsar e uma nova modalidade de crítica literária, abalizada pelos padrões modernos da crítica universitária, investigadora por natureza, fundamentada em argumentações científicas e na sistematização da pesquisa, começa a se organizar, alcançando efetiva concretização na virada dos anos 1950 para os 1960. Em 1958, Candido se afasta institucionalmente da sociologia ao deixar a cadeira de Sociologia II da Faculdade de Filosofia da Universidade de São Paulo (em que atuou como assistente de Fernando de Azevedo entre 1942 e 1958, ao mesmo tempo que praticava a militância crítica na imprensa) e começa a lecionar Literatura na recém-inaugurada Faculdade de Filosofia, Ciências e Letras de Assis, onde se empenhou, como é conhecido, na organização e fundação do curso de Letras, passando a trabalhar na esfera institucional com aquela que era a sua principal matéria no jornalismo crítico (OTSUkA, 2009, p. 108).

Por influência das noções de estrutura e de princípio estrutural extraídas da antropologia social inglesa (em particular dos conceitos de Malinowski e Radcliffe-Brown) e das ideias críticas de T. S. Eliot e dos new critics anglo-americanos, no transcurso dos anos 1950 se desenvolveria a segunda etapa de sua trajetória teórica. Amplificando a noção de forma e/ou estrutura, que deixa de ser compreendida de maneira estritamente técnica (tal como a concebiam as tendências formalistas de inspiração linguística), sua preocupação é o "problema da funcionalidade", isto é: não apenas o encadeamento temporal dos eventos ou das obras e seu condicionamento, mas a "pertinência dos traços de um determinado sistema" (CANDIDO, 2011, p. 4). Situam-se nessa fase Os parceiros do Rio Bonito (tese com que se doutorou em Ciências Sociais, em 1954, pela Universidade de São Paulo, publicada com ligeiras modificações dez anos mais tarde) e o clássico Formação da literatura brasileira, marco da crítica historiográfica de nossa literatura, redigido entre 1945 e 1957 com interrupções, mas publicado em 1959, no qual Candido busca "ver um sentido diacrônico combinado ao respeito pela visão sincrônica" (CANDIDO, 2011, p. 4).

Gostaria de me deter no repertório conceitual em que se fundam as análises desse último livro, porque é nele que se acham as bases do ponto de vista histórico que orienta a perspectiva crítica do autor. Como se sabe, Candido propõe um novo conceito para historiar a formação da literatura nacional. Buscando reconstituir o desejo dos brasileiros de terem uma literatura, ele mostra como e quando se configura o que denomina sistema literário: a integração dinâmica e progressiva entre escritores ("produtores literários, mais ou menos conscientes do seu papel"), leitores ("receptores, formando os diferentes tipos de público") e obras ("mecanismo transmissor", linguagem traduzida em estilos), que se comunicam de modo a criar uma tradição interna, sem a qual não se concebe a literatura como "sinônimo de civilização". É o processo da tradição que institui a consciência da continuidade ininterrupta de escritores e obras ("espécie de transmissão da tocha entre corredores"), e que permite o reconhecimento dos padrões literários precedentes, seja para aceitá-los, seja para rejeitá-los (CANDIDO, 2009, p. 25).

Opostos pela atitude estética, mas articulados pela função histórica, Arcadismo e Romantismo constituiriam os momentos decisivos da formação de nossa literatura como sistema orgânico estruturado. O universalismo domina as concepções neoclássicas e o particularismo, as românticas. Não obstante a ruptura estilística que se opera entre esses dois movimentos, eles se solidarizam no compromisso de inscrever a literatura no processo histórico de elaboração

\footnotetext{
${ }^{4}$ De acordo com D. Arrigucci (1992, p. 195), trata-se de uma expressão do próprio Antonio Candido, que pensou em utilizá-la como título de um ensaio e a empregou com frequência em aulas e conferências.
} 
nacional. Embora visassem a uma realidade individual, os escritores neoclássicos, graças aos moldes universalistas por que se guiavam, articularam a nossa atividade literária com o sistema expressivo da civilização ocidental, dentro da qual definiram paulatinamente a nossa originalidade. Após a Independência política de 1822, o empenho com a vida nacional se manifesta na literatura como parte da tarefa de construir um país livre. A partir do último quartel do século XIX, com os livros maduros de Machado de Assis, o processo formativo da literatura no Brasil se completaria como sistema estável. Assimilando o legado positivo dos antecessores (Macedo, Manuel Antônio e José de Alencar), seu romance finalmente cumpria o programa da continuidade cultural e alcançava a universalidade pelo aprofundamento de sugestões da particularidade local. Noutro passo, ao tratar das correlações entre "Literatura e subdesenvolvimento" na América Latina, assinalaria Candido: pela integração entre localismo e universalismo, numa tomada plena da consciência do subdesenvolvimento, é com Guimarães Rosa que o processo formativo de nossa literatura atingiria seu ponto mais elevado. ${ }^{5}$

Um dos conceitos fundamentais para a compreensão do método crítico de Antonio Candido anunciado nas páginas iniciais da Formação da literatura brasileira (2009) é o de texto como resultado, cuja autonomia não desdenha, para a sua penetração analítica, das condições psíquicas e sociais que o animam e podem estar nele presentes atuando em seus significados. ${ }^{6}$ Com base nesse conceito, são fixados os dois critérios de interpretação. Um é o da representatividade, pelo qual se estabelecem as conexões entre o autor e o seu tempo e entre a obra e o seu tempo. O outro, o do valor intrínseco e/ou do valor estético, voltado a definir as forças de expressão e de construção, ou a importância da organização interna do texto literário. "Na tarefa crítica há, portanto, uma delicada operação, consistente em distinguir o elemento humano anterior à obra e o que, transfigurado pela técnica, representa nela o conteúdo, propriamente dito" (CANDIDO, 2009 , p. 36). O respeito a uma tal correlação entre o fato histórico e o fato estético implica uma atitude crítica que encara simultaneamente o contexto cultural como conjunto de obras entrelaçadas e a obra em sua particularidade e integridade. É justamente a aplicação dessa dupla perspectiva (em obediência ao próprio caráter duplo no qual se concebe a literatura, como indicado mais alto) que permite a Candido mostrar como "certos elementos da formação nacional (dado histórico-social) levam o escritor a escolher e tratar de maneira determinada alguns temas literários (dado estético)" (CANDIDO, 2009, p. 18).

Em Antonio Candido o ato crítico - "a justificativa racional de um juízo literário" (SCHWARZ, 1987, p. 132) - é a dialética, vista como o único método capaz de integrar, no enfrentamento da ficção literária, as contradições que se manifestam tanto no conteúdo transfigurado na forma quanto na forma com que se transfigura esse mesmo conteúdo. $\mathrm{E}$ tal conteúdo, como demonstrou Paulo Arantes (1992), é nada mais nada menos que a experiência social e cultural brasileira, a qual se define pela intrincada relação de dependência e desejo de independência entre a nossa realidade periférica e os padrões dos países centrais do Ocidente. $\mathrm{Ou}$ seja: "um entrelaçamento dual entre o Mesmo e o Outro" (ARANTES, 1992, p. 16). Em "Literatura de dois gumes", a orientação metodológica apareceria reformulada nestes termos: "A atitude adotada pode ser definida como sentimento de contrários, isto é: procura ver em cada tendência a componente oposta, de modo a apreender a realidade da maneira mais dinâmica, que

\footnotetext{
${ }^{5}$ De acordo com A. Candido (2006a, p. 250-251), "Machado de Assis tinha mostrado que num país novo e inculto era possível fazer literatura de grande significado, válida para qualquer lugar, deixando de lado a tentação ao exotismo (quase irresistível no seu tempo). Guimarães Rosa cumpriu uma etapa mais arrojada: tentar o mesmo resultado sem contornar o perigo, mas aceitando-o, entrando de armas e bagagens pelo pitoresco regional mais completo e meticuloso, e assim conseguindo anulá-lo como particularidade, para transformá-lo em valor de todos." O leitor deve ter em mente esse juízo nos desenvolvimentos que se seguem.

${ }^{6}$ Cf. "Os elementos de compreensão", quinta parte da introdução de Formação da literatura brasileira, A. Candido (2009, p. 35-37).

${ }^{7}$ A propósito dessa dupla concepção de historicidade, ver as observações que faz A. Bosi (2002, p. 40-45).
} 
é sempre dialética" (CANDIDO, 2006a, p. 198, grifos meus). Estaria aí a matriz da opção de Candido pelo estilo livre que movimenta os volteios da prosa ensaística.

Teoria, método. Ainda que sempre tenha escapado a abstrações teóricas e evitado descrições metodológicas (não obstante o aparato erudito de que se revestem suas leituras), o fato é que Antonio Candido enfrentou, por meio de uma série de esforços múltiplos, o problema dos elos entre a ficção e a realidade, abordando-o com instrumentos diversos, sem descurar jamais da precedência da estrutura literária. Focado nesse princípio, o alvo da terceira fase, que engloba a sua produção a partir dos anos 1960, é entender o processo mediante o qual os fatores condicionantes se tornam pertinentes ao próprio sistema literário. " $O$ interesse pela funcionalidade leva ao interesse pela estrutura, num sentido diferente dos estruturalistas, pois o que se indaga é como a estrutura se estrutura" (CANDIDO, 2011, p. 4). Os acentos deslocam-se, pelas palavras de Roberto Schwarz (1999, p. 12): "A prioridade passa para a análise estética, ou formal, mas sem que esta dessocialize, o que é um prisma novo, além de resolver um impasse quase secular na crítica brasileira", qual seja: "a relação interna e nunca automática entre literatura e vida social" (SCHWARZ, 2009, p. 54).

A década de 1960 é marcada, sabemos, pela "tensão entre dois polos intelectuais e morais" (BOSI, 2013, p. 243). Paralelamente ao surto do estruturalismo e ao retorno aos formalistas russos, sustentando a leitura imanente rigorosa, ocorre a revivescência do marxismo, que só então passou a ter presença efetiva na cultura universitária. Declarada abertamente dialética, a crítica sociologizante pós-lukacsiana propunha a compreensão da função exercida pela estrutura social na composição literária a partir da conhecida teoria do reflexo:

Na luta sem quartel contra todas as formas de idealismo, os marxistas ortodoxos acabaram apequenando a obra de arte a um decalque das relações sociais (tais como as enxergavam), e tratando os processos simbólicos e imaginários como epifenômenos da máquina econômica vigente. (BOSI, 2002, p. 30).

A verdade é que o marxismo convencional não estava em condições de concretizar uma teoria intrinsecamente dialética, capaz de entabular uma interlocução consistente entre "a criação estética individual e o processo social de uma nação colhido em um determinado período da sua história" (BOSI, 2002, p. 29). Possivelmente em função da filiação do materialismo histórico a certas leis deterministas da sociologia positivista e do evolucionismo assimilados a partir do século XIX, uma teoria fundada na dialética hegeliana com efeito rendia pouco em termos de compreensão da produção literária.

A mesma postura francamente interventiva nos juízos estabelecidos nos mais diversos campos pelos quais se aventurou desde suas colaborações iniciais em jornais e revistas - e que levara Candido a arguir o influxo de tendências formalistas amplamente difundidas nos modelos do estruturalismo francês e do close-reading patrocinado pelos new critics anglo-americanos que se apoderava da crítica literária brasileira a partir dos anos 1950, especialmente por meio da figura de Afrânio Coutinho - é capaz de detectar os riscos do marxismo mecanicista e das posições historiográficas tradicionais.

\footnotetext{
A partir da década de 60, uma parte dos ensaios de Antonio Candido tem como desafio a reversibilidade entre análise interna e análise social. Convencido do interesse desses relacionamentos, bem como da sua dificuldade, o crítico procura torná-los judiciosos, evitando a falta de discriminação reinante na historiografia positivista e naturalista, continuada no marxismo vulgar, tradições para as quais a peculiaridade da esfera literária pouco existia. (SCHWARZ, 1999, p. 29).
}

Ora, num momento em que a crítica internacional tendia ao abandono da referencialidade externa, concebida como "forma irrisória do espelhismo fotográfico", Candido opera um movimento a contrapelo ao procurar precisar e aprofundar as relações entre a literatura e o seu 
enraizamento histórico e social. "Em lugar de debate sobre teses gerais, rapidamente estéril, tratava de detalhar modos de continuidade bem como de ruptura, puxando a discussão para questões de fato, ou seja, para o valor de conhecimento das leituras oferecidas" (SCHWARZ, 1999, p. 29). É nesse contexto que Candido constrói a conhecida formulação segundo a qual o elemento histórico e sociológico externo importa não como causa, nem como significado, mas como fator interno, que desempenha um papel na construção da obra literária - eixo do programa delineado em "Crítica e sociologia (tentativa de esclarecimento)", de 1965, ensaio de abertura de Literatura e sociedade.

Sua intenção ultrapassa a aplicação do simples método das análises sociologizantes alicerçadas em paralelismos e esquemas ideológicos óbvios em que se assentava o marxismo convencional. Ambicionando superar o valo entre o estético e o social, Candido mostra como este atua na essência da obra literária não como referência temática ou contextual, mas na constituição de uma estrutura peculiar.

\begin{abstract}
Quando isto se dá, ocorre o paradoxo assinalado inicialmente: o externo se torna interno e a crítica deixa de ser sociológica, para ser apenas crítica. O elemento social se torna um dos muitos que interferem na economia do livro, ao lado dos psicológicos, religiosos, linguísticos e outros. Neste nível de análise, em que a estrutura constitui o ponto de referência, as divisões pouco importam, pois tudo se transforma, para o crítico, em fermento orgânico de que resultou a diversidade coesa do todo. (CANDIDO, 2010, p. 17).
\end{abstract}

Quaisquer elementos, sociológicos ou não, devem conduzir a uma interpretação coerente e, acima de tudo, a um discurso crítico que seja integral. Um tal percurso se faz possível quando esses mesmos elementos passam a ser vistos como componentes da estruturação, atuando, portanto, sobre a singularidade do valor estético da obra literária. "Estrutura e função simultaneamente consideradas implicam a consideração da forma como história social, do aparente externo à obra como interno a ela, o social e o histórico, por sua vez, na forma" (CHIAPPINI, 1992, p. 171). Nesse sentido, por fugir à tendência corriqueira de tudo explicar mediante dados exteriores, a orientação crítica pautada pela dialética entre estrutura literária e processo social é legítima e possível. "Em compensação não pode ser mais imposta como critério único, ou mesmo preferencial, pois a importância de cada fator depende do caso a ser analisado" (CANDIDO, 2010, p. 17).

Em contraste com a habitual discrição metodológica, as páginas de Literatura e sociedade enfatizam o papel que a estrutura social pode desempenhar na composição literária e faz visível, em contrapartida, a intenção de não absolutizar essa função, ao admiti-la como possível, mas não como "única, suficiente ou universal” (BOSI, 2002, p. 49).

\begin{abstract}
Até hoje é difícil imaginar um instrumento de trabalho mais fino, abrangente e adequado à compreensão do texto literário do que esse que Antonio Candido elaborou com sua proposta teórica e sua incomparável prática de analista de textos, da qual depende, na verdade, a construção de sua teoria. Isso demonstra que antes de tudo ele é um extraordinário leitor, cujo olhar arguto, sensível e imaginativo sabe captar todo o pormenor significativo de uma obra sem perder a mobilidade que lhe dá a compreensão histórica. (ARRIGUCCI, 2010, p. 213). ${ }^{8}$
\end{abstract}

Seu projeto crítico lançaria sementes profundas e seria por certo determinante dos rumos dos estudos literários no Brasil. A verdade é que nenhuma outra vertente, nem a esteticista e a formalista, nem a estruturalista e a fenomenológica, teve entre nós o êxito da chamada crítica sócio-histórica (NUNES, 2009, p. 60). Em 1961, Candido cria, na Universidade de São Paulo, a disciplina Teoria Literária e Literatura Comparada (inicialmente Teoria da Literatura, a partir da

8 A propósito, ver também "Movimentos de um leitor”, de D. Arrigucci (1992). 
qual seria fundado, em 1990, o Departamento de Teoria Literária e Literatura Comparada), assegurando um espaço institucional para esse domínio dos estudos literários. A tradição comparatista acadêmica implantada por Candido constitui decerto um marco na história da literatura comparada no Brasil a partir de sua institucionalização. "O perfil comparatista de Antonio Candido não se limita, entretanto, às atividades docentes. Sua vasta obra crítica e histórica oferece reflexões e interpretações que representam profundas contribuições para o pensamento comparatista brasileiro e latino-americano" (NITRINI, 2010, p. 194). No intuito de definir, na esfera acadêmica, as relações entre literatura e sociedade balizadoras do posicionamento do crítico, que é também professor universitário, consolidando seu programa teórico no âmbito institucional, Candido republica, em 1963, a tese sobre os postulados da crítica romeriana como o primeiro "Boletim de Teoria Literária e Literatura Comparada" da Faculdade de Filosofia, Ciências e Letras da Universidade de São Paulo (WAIZBORT, 2007, p. 103).

As formulações gerais apresentadas em Literatura e sociedade manteriam ligações estreitas, guardadas obviamente as diferenças de enfoque, com as leituras de romance reunidas em Tese e antitese. Todavia, essas mesmas formulações apareceriam de fato nos ensaios analíticos elaborados por Candido desde 1964 e publicados a partir dos anos 1970 - como é o caso das notáveis leituras enfeixadas na primeira parte d'O discurso e a cidade: "Dialética da malandragem" (1970), "Degradação do espaço" (1972), "O mundo-provérbio" (1972) e "De cortiço a cortiço" (1973)." Não por acaso, a concepção de texto como resultado apareceria reformulada no prefácio da coletânea sob o epíteto redução estrutural: processo pelo qual "a realidade do mundo e do ser se torna, na narrativa ficcional, componente de uma estrutura literária", de modo a permitir que esta seja estudada em si mesma, como algo autônomo (CANDIDO, 2004a, p. 9).

Reunindo áreas distintas, embora interceptadas, como a crítica de rodapé, marcadamente circunstancial, a visada historiográfica e a análise estrutural mais elaborada, as leituras de Antonio Candido resumem não apenas o alcance da particularidade de seu julgamento avaliador e de seu projeto crítico de modo geral, mas a história do próprio estado da crítica no Brasil e seus desdobramentos. Visto a voo de pássaro, este recorte cronológico conta um pouco da trajetória desse grande mestre da crítica, um dos pensadores fundamentais e ponto de referência da historiografia e dos estudos literários no país: "Produção intelectual, capacidade didática e contribuição institucional compõem uma carreira acadêmica impecável e acatada" (SCHWARZ, 1999, p. 14).

\section{2. "Sertão-enquanto-Mundo": entre o inventário e a invenção}

\section{E nisto, que conto ao senhor, se vê o sertão do mundo.}

Grande sertão: veredas, Guimarães Rosa (1970, p. 260).

No ano seguinte ao lançamento de Grande sertão: veredas (1956), Antonio Candido publica "O sertão e o mundo" - que seria, sob o título "O homem dos avessos", reunido a outras leituras de romance em Tese e antítese. No prefácio, lemos que os ensaios reunidos no volume estão ligados pelo tema da "divisão ou alteração, seja na personalidade do escritor, seja no universo da sua obra” (CANDIDO, 2006b, p. 9). Nas leituras dos romances de Alexandre Dumas, Eça de Queirós, Joseph Conrad, Graciliano Ramos e Guimarães Rosa, Candido vê repontar o "problema da complexidade contraditória de cada um" - ou, se quisermos, a psicologia demoníaca do herói problemático no romance moderno postulada por Lukács. E define Grande sertão: veredas como "O primeiro grande romance metafísico da literatura brasileira" (CANDIDO, 2006b, p. 10).

\footnotetext{
9 A respeito da dialética nos ensaios sobre Manuel Antônio de Almeida e Aluísio Azevedo, merecem ser relidos "Pressupostos, salvo engano, de 'Dialética da malandragem"” e "Adequação nacional e originalidade crítica", ambos de R. Schwarz (1987, p. 129-155; 1999, p. 24-45).
} 
A representação da realidade local, com forte carga de pitoresco, ao sabor de nossa tradição novelística, apresentada nos estratos superficiais do romance, é reconfigurada pelo tratamento simbólico: "Do mundo documentário ou semidocumentário se desprende em cada entrelinha um universo fabuloso, que enquadra o verdadeiro problema do livro", qual seja: "o dilaceramento de um homem tomado entre o bem e o mal, debatendo sem repouso a validade de sua conduta". Não por acaso, tal problema liga-se ao sentido do demoníaco:

Coerente com a efabulação proposta, Guimarães Rosa entra resolutamente no plano mágico, sugerindo para os comportamentos decisivos um substrato simbólico, dissolvendo-os em comportamentos primordiais, até trazer à baila, como signo máximo que percorre o livro, desde a epígrafe, o arquétipo de todas as divisões do ser: o demônio. (CANDIDO, 2006b, p. 11).

Ainda no prefácio do livro, Candido apresenta ao leitor o perfil dialético de sua crítica, evocada, de resto, pelo próprio título: "Envergando uniforme adequado, (pois sempre é uma casaca de ferro da literatura), o crítico se imagina um Asmodeu dialético e abre as caixas" (CANDIDO, 2006b, p. 11).

O texto introduz-se ressaltando o caráter inventivo ("jorro de imaginação criadora na linguagem, na composição, no enredo, na psicologia") como o traço fundamental do romance de Guimarães Rosa:

Na extraordinária obra-prima Grande sertão: veredas há tudo para quem souber ler, e nela tudo é forte, belo e impecavelmente realizado. Cada um poderá abordá-la a seu gosto, conforme o seu ofício; mas em cada aspecto aparecerá o traço fundamental do autor: a absoluta confiança na liberdade de inventar. (CANDIDO, 2006b, p. 111).

Logo adiante a afirmação é argumentada por uma concepção geral da arte que a vê como desfiguração da realidade objetiva, seu ponto de partida:

\footnotetext{
Para o artista, o mundo e o homem são abismos de virtualidades, e ele será tanto mais original quanto mais fundo baixar na pesquisa, trazendo como resultado um mundo e um homem diferentes, compostos de elementos que deformou a partir dos modelos reais, consciente ou inconscientemente propostos. Se o puder fazer, estará criando o seu mundo, o seu homem, mais elucidativos que os da observação comum, porque feitos com as sementes que permitem chegar a uma realidade em potência, mais ampla e mais significativa. (CANDIDO, 2006b, p. 111).
}

E torna ao específico, recuperando as implicações da invenção como procedimento formal e fundamento da personalidade estética de Rosa. É por intermédio dela que o romancista penetra a matriz do sertão real e a manipula como se este estivesse no estado de "primórdio absoluto, na esfera do puro potencial": "Parecia que, de fato, o autor quis e conseguiu elaborar um universo autônomo, composto de realidades expressionais e humanas que se articulam em relações harmoniosas, superando por milagre o poderoso lastro de realidade tenazmente observada, que é a sua plataforma" (CANDIDO, 2006b, p. 112).

Embora não defina o conceito de invenção, é em torno dele que se desenrola o juízo crítico de Candido. Aliás, é preciso relembrar que não estamos diante de um crítico especulativo, preocupado em definir epistemológica ou filosoficamente as suas passagens, mas de um leitor analítico e interpretativo, que evita a pura abstração; enfim, um crítico exegético por excelência. A invenção ou a imaginação (ou seja, aquilo que supera a ordem da representação) tributada ao 
procedimento literário em Rosa aparece como um critério positivo que avança na avaliação do romance: ${ }^{10}$

\begin{abstract}
A experiência documentária em Guimarães Rosa, a observação da vida sertaneja, a paixão pela coisa e pelo nome da coisa, a capacidade de entrar na psicologia do rústico, tudo se transformou em significado universal graças à invenção, que subtrai o livro à matriz regional para fazer exprimir os grandes lugares-comuns sem os quais a arte não sobrevive: dor, júbilo, ódio, amor, morte, - para cuja órbita nos arrasta a cada instante, mostrando que o pitoresco é acessório e que na verdade o Sertão é o mundo. (2006b, p. 112).
\end{abstract}

Nessa fórmula que baliza a leitura de Candido, acha-se o fulcro de seu juízo: a dialética entre o local e o universal ou entre o inventário (o conjunto de bens, que, no caso, é a matéria social, histórica, política, geográfica e cultural do sertão) e a invenção (aquilo que escapa à representação ou aquilo que não existe: o salto realizado pela imaginação), por intermédio da qual a obra se torna universal.

A organização do ensaio tem como referência a tripartição na obra de Euclides da Cunha. A aproximação entre os livros é justificada nesses termos: "Há em Grande sertão: veredas, como n'Os sertões, três elementos estruturais que apoiam a composição: a terra, o homem, a luta. Uma obsessiva presença física do meio; uma sociedade cuja pauta e destino dependem dele; como resultado o conflito entre homens" (CANDIDO, 2006b, p. 112). Contudo, adverte Candido:

\footnotetext{
Mas a analogia para por aí; não só porque a atitude euclidiana é constatar para explicar, e a de Guimarães Rosa inventar para sugerir, como porque a marcha de Euclides é lógica e sucessiva, enquanto a dele é uma trança constante dos três elementos, refugindo a qualquer naturalismo e levando, não à solução, mas à suspensão que marca a verdadeira obra de arte, e permite a sua ressonância na imaginação e na sensibilidade. (CANDIDO, 2006b, p. 112-113).
}

Fazendo valer o argumento segundo o qual os três planos comparecem na obra de Guimarães Rosa, cujo universo é regido por "leis próprias" que se libertam dos "hábitos realistas de nossa ficção", baralhados, sem nenhuma relação causal, o ensaio é estruturado em torno de três tópicos: 1. A terra; 2. O homem; 3. O problema (englobando a luta, ou seja, a representação da jagunçagem no romance, nas duas primeiras categoriais) (CANDIDO, 2006b, p. 113).

O tópico "A terra" recupera a relação entre observação e construção associada ao processo de invenção transfiguradora ao apontar para a dupla relação do romancista com o meio físico: apoia-se na geografia real do sertão ("O mundo de Guimarães Rosa parece esgotar-se na observação"), por uma parte, e faz dela "suporte ao universo inventado", por outra: "Aos poucos vemos surgir um universo fictício, à medida que a realidade geográfica é recoberta pela natureza convencional” (CANDIDO, 2006b, p. 114). Emblemático do cenário em que real e imaginário se fundem é o São Francisco: "acidente físico e realidade mágica, curso d'água e deus fluvial, eixo do Sertão" (CANDIDO, 2006b, p. 114). Absolutamente determinante no correr da narrativa ("O São Francisco partiu minha vida em duas partes", conforme a ele se refere Riobaldo), sua função no livro é dividir o mundo em dois lados diversos, marcados pelo sentido simbólico que lhes atribui a mentalidade primordial: "O direito é o fasto; nefasto o esquerdo" (CANDIDO, 2006b, p. 114). Na margem direita, os fatos que marcam a primeira parte da vida do jagunço Riobaldo:

\footnotetext{
${ }^{10}$ Como observa D. Arrigucci ao comentar "Realidade e realismo (via Marcel Proust)", ensaio reunido em Recortes, o centro da reflexão de A. Candido desde a crítica jornalística é a forma como a realidade apresenta-se na literatura. É por meio dessa perspectiva que Candido desenvolve na leitura da obra proustiana a consideração de "transrealismo, literariamente mais convincente do que o realismo referencial", por consentir "a liberdade da imaginação mediante a transfiguração do pormenor, que tem o poder de criar uma realidade além da que experimentamos" (ARRIGUCCI, 2010, p. 217). A esse respeito, ver também L. Waizbort (2007, p. 247-248).
} 
"Margem do grande chefe justiceiro Joca Ramiro; do artimanhoso Zé Bebelo; da vida normal no Curralinho; da amizade reta (apesar da revelação na Guararavacã do Guaicuî) por Diadorim, mulher travestida em homem." $\mathrm{Na}$ esquerda, os acontecimentos que se sucedem ao assassinato de Joca Ramiro: "Margem da vingança e da dor, do terrível Hermógenes e seu reduto no alto Carinhanha; das tentações obscuras; das povoações fantasmais; do pacto com o diabo" (CANDIDO, 2006b, p. 114). Unindo os dois lados, as águas do São Francisco: local do primeiro encontro de Riobaldo com o Menino, mais tarde Diadorim, que decidiria o destino do narrador e que lembra em dimensão rústica o de Stefan George com Maximin do ciclo Der siebente Ring, pela "presença de valores transcendentais encarnados entre os homens" (CANDIDO, 2006b, p. 115). E a experiência da travessia: "Simbolicamente, eles vão e vêm de uma a outra margem, cruzando e tocando as duas metades qualitativas do Sertão, do mundo, pois Diadorim é uma experiência reversível que une o fasto e o nefasto, lícito e ilícito, sendo ele próprio duplo na sua condição" (CANDIDO, 2006b, p. 115).

Num único lance, ao armar a leitura da constituição do espaço no romance, Candido faz com que o leitor se aperceba da ligação simbólica entre a divisão do mundo e o tema da divisão do ser, que se associa, por sua vez, ao significado da complexa e enigmática presença da personagem de Diadorim na trajetória do protagonista-narrador Riobaldo. Através dessas articulações, o crítico antecipa ainda aqueles que seriam os elementos estruturadores da narrativa: a ambiguidade e a reversibilidade, achados fundamentais na recepção do romance e que estão na base das relações entre localismo e universalismo em Rosa. Para expressar a ambivalência do meio físico, o real e o fantástico coexistindo "amalgamados na invenção e, as mais das vezes, dificilmente separáveis", Candido cunha o termo heterolateralidade. Ambivalência que se mostra, além do mais, na função exercida pela topografia, "variável, conforme a situação" (CANDIDO, 2006b, p. 116). É o caso, indica o ensaísta, da passagem ao final do livro em que Riobaldo, egresso da jagunçagem, volta à encruzilhada onde invocara o demo e descobre que as VeredasMortas jamais existiram e que se trata na verdade das Veredas-Altas - "o aparente local do contrato se evapora no mistério" (CANDIDO, 2006b, p. 116). Ainda, outro caso mais típico é o Liso do Sussuarão, simultaneamente "intransponível e transponível": sob a chefia de Medeiro Vaz, a travessia a fim de emboscar Hermógenes em terra baiana falha. Mais tarde, com o pactuário Riobaldo no comando, ela é realizada com relativa facilidade. A oscilação dessas paragens em obediência às circunstâncias não implica causalidade do meio físico, porque seu caráter é mais simbólico que real: "A variação da paisagem, inóspita e repelente num caso, sofrível no outro, foi devida ao princípio de adesão do mundo físico ao estado moral do homem, que é uma das partes da visão elaboradas no livro" (CANDIDO, 2006b, p. 116, grifo nosso).

Mas, se a terra obedece ao estado moral do homem, por um lado, essa mesma terra é quem lhe determina, por outro, as regras do viver: "A outra parte é simetricamente inversa, porque os homens, por sua vez, são produzidos pelo meio físico. O Sertão os encaminha e desencaminha, propiciando um comportamento adequado à sua rudeza." (CANDIDO, 2006b, p. 117). Nestes termos, Candido abre o tópico "O homem", enfocando os processos sociais formalizados no romance, em particular, as condições de constituição e o modus vivendi do jagunço no universo representado. Tais aspectos seriam posteriormente retomados e ampliados pelo crítico em "Jagunços mineiros de Cláudio a Guimarães Rosa", ensaio que aborda detidamente a origem do valentão armado e a sua representação na literatura, sobretudo na ficção regionalista.

Um dos elementos que caracteriza o jagunço de Guimarães Rosa é a dimensão individualizante. Cada integrante do bando tem seus motivos e justificativas para aliciar-se ao banditismo: "O Sertão transforma em jagunços os homens livres, que repudiam a canga e se redimem porque pagam com a vida, jogada a cada instante. Raros são apenas bandidos, e cada um chega pelos caminhos mais diversos" (CANDIDO, 2006b, p. 118). Tendo cada qual as suas razões morais, ninguém - com exceção de Hermógenes - nasce bandido: "Quer dizer que, naquele sertão, o jaguncismo pode ser uma forma de estabelecer e fazer valer normas, o que 
torna o jagunço um tipo especial de homem violento e, por um lado, o afasta do bandido" (CANDIDO, 2004b, p. 112). Nesse mundo em que as condutas são reversíveis, não se divisa o bandido e o não-bandido: "O mesmo homem pode ser hoje soldado e amanhã jagunço, ou o contrário" (CANDIDO, 2004b, p. 112). É o caso de Zé Bebelo: em nome de uma certa utopia política, pretende inicialmente civilizar o sertão e abolir o jaguncismo tornando-se deputado em favor da lei e do governo. "Derrotado pelos jagunços, julgado numa cena onde o livro alcança o nível da mais alta literatura, a principal acusação que recebe é a de querer mudar a lei que rege aqueles bomens." (CANDIDO, 2006b, p. 117, grifo nosso). Mais adiante, Zé Bebelo transforma-se em chefe de jagunços, muito embora continue agindo imbuído de tarefa patriótica, e acaba fazendeiro com planos de mudar-se para a capital, tornar-se homem da cidade. Além do tema da relatividade, através da caracterização da personagem de Zé Bebelo e do episódio central do julgamento dele por Joca Ramiro e seus jagunços na Fazenda Sempre-Verde, Candido põe em foco o conflito entre o sertão e a cidade ou, mais especificamente, o contraste entre a lei de usos e costumes e a lei institucional que, como sabemos, caracterizou a República Velha, período representado no romance. O reconhecimento da encarnação do processo histórico nas personagens, mediante a análise das relações de continuidade e descontinuidade que essas mesmas personagens estabelecem com o referente, solução metodológica de Candido, viria a representar outro grande achado crítico.

Um traço do jagunço de Guimarães Rosa é a ambiguidade. Ele não se apresenta como mero salteador, mas como "um tipo híbrido entre capanga e homem-de-guerra" (CANDIDO, 2006b, p. 119). A atribuição de qualidades ideais ao banditismo sertanejo, que se caracterizou, por vezes, como expressão de revolta contra as iniquidades sociais, resultando num modo de violência justiceira, estaria expressa na força do arrojo que o bando de jagunços, qualificando a si próprios de guerreiros, empreende contra a máquina econômica que vem encarnada na figura de fazendeiros como seô Habão. A idealização da jagunçagem é vista no gesto simbólico de Medeiro Vaz, ao atear fogo na casa de fazenda herdada dos antepassados e sair montado em ginete para impor justiça no sertão.

As considerações acerca da tipologia humana do romance confluem para o reconhecimento da presença de elementos que transcendem a perspectiva localista e objetivista da representação do jagunço: "Escritor genial, dos poucos que aguentam esse qualificativo em nossa literatura, Guimarães Rosa supera e refina o documento, que não obstante conhece exaustivamente e cuja força sugestiva guarda intacta, por meio da sublimação estética" (CANDIDO, 2004b, p. 115). E levam Candido (2004b, p. 113) a identificar na recriação rosiana desse tipo social historicamente específico uma ontologia peculiar, um "ser jagunço como forma de existência, como realização ontológica no mundo do sertão". A superação da realidade documentária em Rosa é denunciada ademais no apagamento relativo de marcas temporais e referências geográficas do sertão real, dimensões habituais no tratamento da jagunçagem em nossa ficção. As esparsas notações que aparecem ao longo da narrativa com relação a nomes da força pública, ou proprietários rurais, ou ainda as alusões remotas e praticamente legendárias a cidades figuram uma espécie de moldura do momento histórico que, por sua vez, se combina com um movimento de abstração da realidade sertaneja representada na narrativa.

\subsection{Riobaldo: o jagunço paladino}

Com a dureza de querer, que espremi de minha sustância vexada, fui sendo outroeu mesmo senti: eu Riobaldo, jagunço, homem de matar e morrer com a minha valentia. Riobaldo, homem, eu, sem pai, sem mãe, sem apego nenbum, sem pertencências.

Grande sertão: veredas, Guimarães Rosa (1970, p. 155). 
Um dos elementos que explicam a ontologia peculiar do valentão sertanejo em Guimarães Rosa é a sua contaminação pela legenda dos homens d'armas medievais. "De fato, percebemos que assim como acontece em relação ao meio, há um homem fantástico a recobrir ou entremear o sertanejo real; há duas humanidades que se comunicam livremente, pois os jagunços são e não são reais" (CANDIDO, 2006b, p. 119). A caracterização dos jagunços como forma de paladino, aproximando o romance da ficção medieval, constitui uma das linhas centrais de "O homem dos avessos". Segundo Candido, eles seriam comparáveis a avatares do romance de cavalaria, o que esclarece, de resto, a transcendência da realidade do banditismo político: "Sobre o fato concreto e verificável da jagunçagem, elabora-se um romance de Cavalaria, e a unidade profunda do livro se realiza quando a ação lendária se articula com o espaço mágico” (CANDIDO, 2006b, p. 119).

Pela presença de certos ideais que habitam o imaginário do romance de cavalaria, a jagunçagem supera a esfera ordinária ditada pela regra do matar ou morrer, "existência em fio-denavalha" (CANDIDO, 2006b, p. 117). Assim como os paladinos, os jagunços representados no livro são regidos por um código de ética coorporativo e estrito ("um verdadeiro bushidô, que regula a admissão e a saída, os casos de punição, os limites da violência, as relações com a população, a hierarquia, a seleção do chefe"), cuja norma fundamental é lealdade para com o bando e para com o líder (CANDIDO, 2006b, p. 120). "No código do jagunço, roubar é crime, mas cabe a coleta de tributos - extorsões em dinheiro e requisições de gado, para manter o bando" (CANDIDO, 2006b, p. 119). Sua conduta guardaria, ademais, proximidades com os cavaleiros medievais como de fato existiram, desempenhando funções parecidas com as dos jagunços numa sociedade também sem centralização de poder e pautada pela competição de grupos rurais. São muitos os exemplos de movimentos sociais marcados pela prática de extorsão e saque, sinaliza ainda o ensaísta, como é o caso dos Raubritter alemães.

Por meio do paralelismo com a legenda, o ensaio prepara o leitor para considerações mais complexas que embasam a lógica constitutiva da narrativa rosiana. A genealogia medieval do romance justificaria as batalhas e os duelos, os ritos e as práticas. Outro sinal dos padrões medievais é a carreira do protagonista-narrador Riobaldo, de nascimento ilegítimo como os paladinos Roldão e Tristão. A contaminação da obra por práticas e lendas medievais articula-se com constantes mais fundas, tocando as categorias do rito e do mito. E esse mito é nada mais nada menos que o velho motivo literário do pacto com o diabo. Como nos ritos iniciatórios contidos em certos romances de cavalaria e, de algum modo, na própria cavalaria militante, o pacto com o diabo simboliza o modo pelo qual Riobaldo adquire "força intima" para assumir o comando outrora recusado (CANDIDO, 2006b, p. 121, grifo nosso): "O diabo surge então, na consciência de Riobaldo, como dispensador de poderes que se devem obter; e como encarnação das forças terríveis que cultiva e represa na alma, a fim de couraçá-la na dureza que permitirá realizar a tarefa em que malograram os outros chefes." (CANDIDO, 2006b, p. 122). É o caminho para dar cabo do assassino de Joca Ramiro, alvo supremo de Diadorim: "Para vencer Hermógenes, que encarna o aspecto tenebroso da Cavalaria sertaneja, - cavaleiro felão, traidor do preito e da devoção tributados ao suserano, - é necessário o paladino penetrar e dominar o reino das forças turvas" (CANDIDO, 2006b, p. 122).

Candido elenca ainda sinais da mudança brusca no protagonista após o rito de iniciação simbolizado pela sanção do pacto: "Em Grande sertão: veredas, Riobaldo sai transformado, endurecido, arbitrário, roçando a crueldade, na prepotência das funções de mando que logo assume, em contraste com a situação anterior, em que as tinha rejeitado" (CANDIDO, 2006b, p. 123). Tomando como referência a missão de Riobaldo, a vingança contra o bando traidor de Hermógenes e Ricardão, após o suposto pacto, ocorre uma inflexão do processo narrativo, acrescenta o ensaio sobre a representação do jaguncismo mineiro na literatura. Seguindo "uma espécie de peregrinação caprichosa pelo mundo", o pactuário Riobaldo é capaz de realizar feitos prodigiosos: "Encastelado no novo modo de ser, dele emana uma espécie de força que promove a eficácia da ação, como se o ato fosse produzido por uma misteriosa energia espiritual" 
(CANDIDO, 2004b, p. 119). Além das mencionadas relações com os romances de cavalaria, Candido reconhece outro aspecto de caráter mágico ou ritual que perpassa a trajetória do protagonista-narrador. A sucessão dos chefes seria comparável aos mitos e ritos agrários das sociedades primitivas: "Ao ritual da Capela Perigosa, junta-se esse vislumbre de simbolismo sacrificial para compor o plano de fundo do livro, acentuando o revestimento mágico do jagunço paladino" (CANDIDO, 2006b, p. 124, grifo nosso).

Tais considerações acerca do poder recíproco da terra e do homem deságuam na formulação de que a dialética do livro se explica pelo "princípio geral da reversibilidade", que lhe confere "um caráter fluido e uma misteriosa eficácia" (CANDIDO, 2006b, p. 125). A esse princípio estariam ligados os diversos estratos da ambiguidade do romance:

\begin{abstract}
Ambiguidade da geografia, que desliza para o espaço lendário; ambiguidade dos tipos sociais, que participam da Cavalaria e do banditismo; ambiguidade afetiva, que faz o narrador oscilar, não apenas entre o amor sagrado de Otacília e o amor profano da encantadora "militriz" Nhorinhá, mas a face permitida e a face interdita do amor, simbolizada na suprema ambiguidade da mulher-homem que é Diadorim; ambiguidade metafísica, que balança Riobaldo entre Deus e o Diabo, entre a realidade e a dúvida do pacto, dando-lhe o caráter de iniciado no mal para chegar ao bem. (CANDIDO, 2006b, p. 125).
\end{abstract}

Acoplando a labilidade entre polos à fusão de contrários, esses planos são exprimidos na ambiguidade do estilo, matriz do romance, que concilia "popular e erudito, arcaico e moderno, claro e escuro, artificial e espontâneo" (CANDIDO, 2006b, p. 125). Assim, Grande sertão abriria ao leitor misturas em que se cortam "mágico e lógico, lendário e real", oscilando entre "o aparente e o oculto, o dado e suposto", e sua coerência interna viria da reunião desses extremos, em que a fusão entre o homem e a terra se manifesta dialeticamente num terceiro termo: "Sertãoenquanto-Mundo" (CANDIDO, 2006b, p. 125).

\title{
2.2. O herói problemático e o tema da divisão do ser
}

Eu era dois, diversos? O que não entendo hoje, naquele tempo eu não sabia. Grande sertão: veredas, Guimarães Rosa (1970, p. 369)

Acompanhando a ordem das ideias discutidas, o último tópico de "O homem dos avessos" atinge o "verdadeiro problema do livro", conforme anuncia Candido (2006b, p. 11, grifo nosso) no prefácio de Tese e antítese: "a velha Sombra, o lado negativo, a projeção suprema do Eu conturbado", encarnando "o angustiado debate sobre a conduta humana e os valores que a escoltam" (CANDIDO, 2006b, p. 125). Trata-se do dilaceramento do velho jagunço Riobaldo, retirado das lides, laboriosamente às voltas com a construção da sabedoria sobre a experiência vivida, buscando descobrir, numa contenda incessante, o sentido de seus atos e dos acontecimentos de sua vida. Candido chama a atenção para os desdobramentos do foco narrativo em primeira pessoa e, em particular, para a relação entre o tempo do narrado e o tempo da narração. Esse aspecto reapareceria com maior extensão no ensaio sobre a jagunçagem na literatura mineira, indicando a relação entre o foco narrativo, a representação da violência e a interioridade do protagonista: "Trata-se, com efeito, de ver o mundo através dum ângulo de jagunço, resultando um mundo visto como mundo-de-jagunço"(CANDIDO, 2004b, p. 120-121). Ao lado do salto dado pela focalização no tratamento da matéria (a representação da violência no sertão instituída pelo campo de consciência de um agente da brutalidade), o recurso adotado por Rosa, articulando o duplo tempo (tempo do narrado e tempo da narração) e, por conseguinte, a dupla perspectiva (a do jagunço Riobaldo e a do velho Riobaldo), favorece a paridade entre o dilaceramento do narrador e o dilaceramento do mundo, dimensões reciprocamente implicadas. 
O símbolo escolhido para dinamizar a recorrência do tema do dilaceramento humano é o diabo. Ao encararmos a individualidade do velho Riobaldo, o demônio - símbolo da duplicidade primordial, forma arquetípica de todas as divisões do ser, conforme dito - adquire significado algo diferente do que fora apontado sob o aspecto iniciatório do jagunço Riobaldo, incorporando agora a problemática existencial, as tensões da alma, a essência torva da personalidade, simbolizando, enfim, como para o Fausto de Goethe ou para Peter Schlemilh de Adelbert von Chamisso, "a tentação e o mal" (CANDIDO, 2006b, p. 125). A vigência do demônio, entidade refutada, mas jamais negada, indecisão absoluta e ambiguidade que perpassa todas as páginas do livro, é o núcleo das especulações de Riobaldo (“O diabo existe e não existe?”). Por um lado, é uma figura abstrata, uma vez que o pacto não é selado em sua forma clássica: "Invocou-o nas Veredas-Mortas e ele não apareceu fisicamente. Isto lhe serve para se tentar convencer de que não houve pacto" (CANDIDO, 2006b, p. 125). Por outro, são inegáveis as mudanças evidentes e os feitos prodigiosos após o ritual na encruzilhada.

"Mas porque o demônio nisso tudo?" - interroga Candido (2006b, p.127) à maneira de retomar a simbologia do demoníaco e indicar a racionalização da reelaboração do mito no romance: "Por que nada encarnaria melhor as tensões da alma nesse mundo fantástico, nem explicaria mais logicamente certos mistérios inexplicáveis do Sertão." O pacto com o diabo decorre da fidelidade de Riobaldo a Diadorim - "andrógino e terrível como os anjos" -, que primeiro o trouxe para a jagunçagem e depois o contaminou com a ânsia por vingança (CANDIDO, 2004b, p. 118): "O demônio surge, então como um acicate permanente, estímulo para viver além do bem e do mal; e bem pesadas as coisas, o homem no Sertão, o homem no Mundo, não pode deixar de existir doutro modo a partir duma certa altura dos problemas" (CANDIDO, 2006b, p. 128). Acolhendo essa visão, Diadorim, personagem cuja "estrutura de ambiguidades é infinita", apresenta-se como instrumento de transcendência, dado que o cumprimento de seu desejo significa em Riobaldo a assimilação de um destino jagunço que supera os limites do documento.

Justamente a busca de liberdade - "esforço para abrir caminho" - é que conduz Riobaldo à encruzilhada das Veredas-Mortas: "A ação serve para confirmar o pensamento, para dar certeza da liberdade" (CANDIDO, 2006b, p. 128). Nesse sentido, o pacto diabólico representa o ponto de viragem no destino do protagonista: "Riobaldo caminha para ele e o alcança através do pacto, que é ao mesmo tempo ascese (sob o aspecto iniciatório) e compromisso (sob o aspecto moral), confirmando a sua qualidade como jagunço" (CANDIDO, 2006b, p. 129, grifos nossos).

$\mathrm{O}$ trato com o diabo aparece, nessa perspectiva, como um instrumento de transcendência da representação histórica em Rosa: "O pacto deixa ver de maneira mais clara o enxerto de um jagunço simbólico no jagunço comum, e a sua função transformadora é nítida no cuidado com que o autor baralha bruscamente as condições normais do espaço" (CANDIDO, 2004b, p. 118). Sujeito que se ajusta às exigências do meio, o jagunço Riobaldo, ao manipular o mal para atingir o bem possível no sertão, sob o risco de perder a alma, dispondo da própria individualidade em favor do bando, transcende o estado de bandido e faz-se inteiramente paladino:

Bandido e não-bandido, portanto, é um ser ambivalente, que necessita revestir-se de certos poderes para definir a si mesmo. O pacto desempenha esta função na vida do narrador, cujo Eu, a partir desse momento, é de certo modo alienado em benefício do Nós, do grupo a que o indivíduo adere para ser livre no Sertão, e que ele consegue levar ao cumprimento da tarefa de aniquilar os traidores, os "Judas". (CANDIDO, 2006b, p. 129).

Todavia, sobrevindo-lhe a inatividade, a face derradeira do velho Riobaldo, fazendeiro assentado, desfaz, em consonância com a reversibilidade que norteia a lógica do livro, o estado pregresso da excepcionalidade momentânea do ideal paladínico: "Os seus feitos tenderam mesmo a aniquilar a condição de jagunço-bandido, e ele se justifica aos próprios olhos nessa negação do 
ser de exceção, em benefício da existência comum, na fazenda que herdou do padrinho (e pai), ao lado de Otacília, prêmio das andanças" (CANDIDO, 2006b, p. 129).

Candido encerra o ensaio apontando para o resultado produzido pela combinação fluida de mito e logos temporalizada na narrativa de Riobaldo: "Desliza, então, entre o real e o fantástico, misturados na prodigiosa invenção de Guimarães Rosa como lei da narrativa. E nós podemos ver que o real é ininteligível sem o fantástico, e que ao mesmo tempo este é o caminho para o real." (CANDIDO, 2006b, p. 130, grifo do autor). Como se vê, a análise dos elementos constitutivos em Rosa por Candido alimenta-se, sobretudo, da dialética entre o local e o universal e disciplinase nela: "O que está dentro e se faz palavra é ora ressoo, ora contraponto do que está fora", na bela e perspicaz definição de Alfredo Bosi (2002, p. 48). "E este é o sumo do ensaio pioneiro de Antonio Candido sobre Grande sertão: veredas, que dá o devido lugar e peso às instâncias míticas pelas quais Guimarães Rosa penetrou no real natural e histórico, o Sertão, descrevendo-o, transfigurando-o, universalizando-o" (BOSI, 2002, p. 48).

\section{REFERÊNCIAS BIBLIOGRÁFICAS}

ARANTES, Paulo Eduardo. Sentimento da dialética na experiência intelectual brasileira: dialética e dualidade segundo Antonio Candido e Roberto Schwarz. São Paulo: Paz e Terra, 1992.

Um departamento francês de ultramar: estudos sobre a formação da cultura filosófica uspiana (uma experiência nos anos 60). São Paulo: Paz e Terra, 1994.

ARRIGUCCI JR., Davi. Movimentos de um leitor: ensaio e imaginação crítica em Antonio Candido. In: D'INCAO, M. A., SCARABOTOLO, E. F. (Orgs.). Dentro do texto, dentro da vida: ensaios sobre Antonio Candido. São Paulo: Companhia da Letras/Instituto Moreira Salles, 1992. p. 181-204.

Questões sobre Antonio Candido. In: O guardador de segredos. São Paulo: Companhia das Letras, 2010. p. 211-218.

BOSI, Alfredo. Literatura e resistência. São Paulo: Companhia das Letras, 2002. Entre a literatura e a história. São Paulo: Ed. 34, 2013.

CANDIDO, Antonio. O método crítico de Sílvio Romero. São Paulo: EDUSP, 1988.

. Textos de intervenção. Seleção, apresentação e notas de Vinicius Dantas. São Paulo: Duas Cidades, 2002.

2004a.

O discurso e a cidade. 3. ed. São Paulo: Duas Cidades; Rio de Janeiro: Ouro sobre Azul,

Vários escritos. 4. ed. São Paulo: Duas Cidades; Rio de Janeiro: Ouro sobre Azul, 2004b.

Jean Maugüé, un obscur éclat. Europe Revue Littéraire Mensuelle, Paris, v. 83, n. 919-920, nov./dez. 2005, p.124-129.

- A educação pela noite. 5. ed. Rio de Janeiro: Ouro sobre Azul, $2006 a$.

Tese e antítese. 5. ed. Rio de Janeiro: Ouro sobre Azul, 2006b.

Clima. In: . Teresina etc. 3. ed. Rio de Janeiro: Ouro sobre Azul, 2007. p. 141-156.

Formação da literatura brasileira: momentos decisivos. 12. ed. São Paulo: FAPESP; Rio de

Janeiro: Ouro sobre Azul, 2009.

Literatura e sociedade. 11. ed. Rio de Janeiro: Ouro sobre Azul, 2010.

Entrevista. Trans/Form/Ação, Marília, v. 34, 2011, p. 3-13.

CHIAPPINI, Ligia. Os equívocos da crítica à Formação. In: D'INCAO, M. A., SCARABOTOLO, E. F. (Orgs.). Dentro do texto, dentro da vida: ensaios sobre Antonio Candido. São Paulo: Companhia da Letras/Instituto Moreira Salles, 1992. p. 170-177. 
NITRINI, Sandra. Literatura comparada: história, teoria e crítica. 3. ed. São Paulo: Edusp, 2010.

NUNES, Benedito. A clave do poético. Organização e apresentação de Victor Sales Pinheiro. São Paulo: Companhia das Letras, 2009.

OTSUKA, Edu Teruki. Literatura e sociedade hoje. Literatura e Sociedade, São Paulo, n.12, 2009, p.104-115.

PONTES, Heloisa. Ar de família: a turma de Clima. Literatura e Sociedade, São Paulo, n. 12, 2009, p. 62-73.

Destinos mistos: os críticos do Grupo Clima em São Paulo (1940-1948). 4. ed. São Paulo: Companhia das Letras, 1998.

ROSA, João Guimarães. Grande sertão: veredas. 7. ed. Rio de Janeiro: J. Olympio, 1970.

SCHWARZ, Roberto. Que horas são?: ensaios. São Paulo: Companhia das letras, 1987. . Sequências brasileiras. São Paulo: Companhia das Letras, 1999.

. Entrevista. Literatura e Sociedade, São Paulo, n. 11, São Paulo, 2009, p. 54-57.

WAIZBORT, Leopoldo. A passagem do três ao um: crítica literária, sociologia, filologia. São Paulo: Cosac Naify, 2007. 